\title{
Sağl1k Hizmetleri ve Yönetiminde Yapay Zekâ
}

\section{Artificial Intelligence in Health Services and Management}

\author{
Betül Akalın ${ }^{1}$ (), Ülkü Veranyurt ${ }^{2}$ (1)
}

${ }^{1}$ (Dr. Öğr. Üyesi), Sağlık Bilimleri Üniversitesi, Hamidiye Sağlık Bilimleri Fakültesi, Sağlık Yönetimi Bölümü, İstanbul, Türkiye

${ }^{2}$ Sağlık Bilimleri Üniversitesi, Hamidiye Sağlık Bilimleri Fakültesi, Sağlık Yönetimi Bölümü, İstanbul, Türkiye

ORCID: B.A. 0000-0003-0402-2461;

Ü.V. 0000-0003-4838-3373

Corresponding author:

Betül AKALIN

Sağlık Bilimleri Üniversitesi, Hamidiye Sağlık Bilimleri Fakültesi, Sağlık Yönetimi Bölümü,

İstanbul, Türkiye

E-mail address: betul.akalin@sbu.edu.tr

Submitted: 30.12 .2020

Revision Requested: 05.02 .2021

Last Revision Received: 07.02.2021

Accepted: 18.03 .2021

Published Online: 20.04 .2021

Citation: Akalin, B. ve Veranyurt, U. (2021). Sağlık hizmetleri ve yönetiminde yapay zekâ. Acta Infologica, 5(1), 231-240. https://doi.org/10.26650/acin.850857
Öz

Günümüzde artan kronik hastalıklar, Covid-19 pandemisi gibi salgınlar, ortalama insan ömrünün uzamasına bağlı olarak artan yaşlı nüfusun evde bakım hizmetlerine olan ihtiyacının artışı ve sağlık okuryazarlığının gelişmesine paralel olarak bireylerin sağlık hizmetlerinden beklentilerindeki değişiklikler; sağlık hizmetleri ve yönetiminde de değişimi beraberinde getirmektedir. Sağlık hizmetleri ve yönetimi, sağlık sektörü ve diğer sektörlerin işbirliği ile geniş kitlelere hitap etmektedir. Sağlık profesyonelleri ile birlikte diğer meslek gruplarının bir arada koordineli bir şekilde çalışabilmesi gerekmektedir. Bunun yanında hastalıkların tanı, tedavi, rehabilitasyonunda ve toplum sağlığının geliştirilmesinde sağlık hizmetlerinin yönetiminde sağlık bilgi teknolojilerinin kullanımına ihtiyaç vardır. Tüm bunlar dikkate alındığında, artan iş yükü yanında yetersiz sayıdaki sağlık insan gücü sebebi ile sağlık hizmetleri ve yönetiminde yapay zekâ uygulamalarının kullanılması kaçınılmazdır. Sağlık alanında ve teknolojide güncel gelişmeler doğrultusunda hasta odaklı dijital bir sağlık ekosistemi yaratılmaya başlanmıştır. Umut vaat eden çözümleriyle yapay zekâ uygulamalarının kullanımında gerekli yasal düzenlemelerin yapılması önerilmektedir.

Anahtar kelimeler: Sağlık Hizmetleri, Sağlık Hizmetleri Yönetimi, Yapay Zekâ

\begin{abstract}
Increasing chronic diseases and epidemics, such as the Covid-19 pandemic, shows a greater need in home care services of the elderly population due to the prolongation of the average human life span and changes in the expectations of individuals from health services in parallel with the development of health literacy. It also brings about change in health services and management. The cooperation of health services and management, the health sector and other sectors would benefit a wide audience. Health professionals and other occupational groups should be able to work in coordination. In addition, there is a need to use health information technologies in the diagnosis, treatment, rehabilitation of diseases and in the management of health services for the development of public health. Considering all of these, it is inevitable to use artificial intelligence applications in healthcare services and management due to the increasing workload and insufficient number of health workers. A patient-oriented digital health ecosystem is being created in line with current developments in healthcare and technology. It is recommended to make the necessary legal regulations in the use of artificial intelligence applications with promising solutions. Keywords: Healthcare, Healthcare Management, Artificial Intelligence
\end{abstract}




\section{Giriş}

Sağlık hizmetleri ve yönetimi, sağlık sektörü ile diğer sektörlerin işbirliği sayesinde geniş kitlelere hitap etmektedir. Sağlık profesyonelleri ile birlikte diğer meslek gruplarının koordineli bir şekilde çalışmasını gerektirmektedir. Bunun yanında hastalıkların tanı, tedavi, rehabilitasyonunda, toplumun sağlı düzeyinin geliştirilmesinde ve sağlık hizmetlerinin yönetiminde çeşitli teknolojik yöntemlere ve araçlara ihtiyaç vardır. ${ }^{1}$ Günümüzde artan kronik hastalıklar, Covid-19 pandemisi gibi salgınlar, ortalama insan ömrünün uzamasına bağlı olarak artan yaşlı nüfusun evde bakım hizmetlerine ihtiyacının artışı ve sağlık okuryazarlığının gelişmesine paralel olarak bireylerin sağlı hizmetlerinden beklentilerindeki değişiklikler; sağlık hizmetleri ve yönetiminde de değişimi beraberinde getirmektedir. Tüm bunlar dikkate alındığında artan iş yükü yanında yetersiz sayıdaki insan gücü sebebi ile sağlık hizmetleri ve yönetiminde yapay zekâ uygulamalarının kullanılması kaçınılmazdır. ${ }^{2}$

Yapay zekâ, insan beyninin fonksiyonlarını temel alarak, insana özgü düşünme, yorum yapabilme, çözümleme, karar verme gibi yetilerin bilgisayar, robot, program gibi sistemlere aktarılması olarak tanımlanabilir. ${ }^{3}$

Sağlık yönetiminde yapay zekâ uygulama alanları oldukça geniş kapsamlıdır. Dünyada pek çok ülkede yapay zekâ uygulamaları, ulusal ve bölgesel sağlık kurum/kuruluşlarının genel idari kararların tespit edilmesinde, alınmasında ve yürütülmesinde kullanılmaktadir.

Türkiye'de Sağlık Bakanlığı; Microsoft, Oracle gibi teknoloji firmalarının ürünlerini kullanmaktadır. Bakanlığın sahip olduğu yapay zekâ uygulamaları; MHRS (Merkezi Hekim Randevu Sistemi) kullanım oranları, Aile hekimliği performans raporları, hastaneye yatış, ameliyat, tanı vb. raporlar, eNabız değerlendirme raporlarıdır. ${ }^{4}$

Sağlık hizmetleri ve yönetiminde yapay zekâ uygulamaları gün geçtikçe popülerlik kazanmaktadır. Sağlık hizmetlerinde yapay zekâ uygulamalarının kullanılması için dünya genelinde pek çok bilimsel çalışma yapılmaktadır. Günümüzde geleneksel sağlık hizmetlerinde yapay zekâ uygulamaları kullanılması yönünde adımlar atılmaktadır.

Sağlık hizmetlerinde ve yönetiminde yapay zekâ uygulamaları, süreçlerde maliyetlerin azaltılması, kalitenin arttırılması, insan kaynaklı hataların azaltılması ve performansın arttırılması amacıyla kullanılmaktadır. Covid-19 pandemisinin başlamasıyla birlikte dünya sağlık sistemi öngörülemez bir talep ile karşılaşmıştır. Bu noktada hastanelerin kapasitelerini öngörmek güçleşmektedir. Yapılan bir çalışmada makine öğrenmesi tabanlı bir Covid-19 kapasite planlama ve analiz sistemi geliştirilmiştir (Capacity Planning and Analysis System (CPAS)). Bu sistem İngiltere'de belirli hastanelerde kurulmuş olup NHS (National Health Service) tarafından onaylı şekilde kullanılmaktadır. ${ }^{5}$ Sağlık yöneticilerinin ve sağlık profesyonellerinin iş süreçlerinde yapay zekâ uygulamalarını kullanabilmeleri için gerekli yasal düzenlemelerin yapılması önerilmektedir.

Bu çalışmada, ülkemizden ve dünyadan sağlı hizmetleri ve yönetiminde kullanılan/kullanılabilecek yapay zekâ uygulamalarına örnekler verilerek, sağlıkta yapay zekânın kullanılabileceğini belirtmek amaçlanmıştır.

\section{SAĞLIK HIZZMETLERİ SUNUMUNDA VE YÖNETIMINDE YAPAY ZEKÂNIN ÖNEMİ}

Sağlık hizmetlerinin sunumunda ve yönetiminde meydana gelen hatalar ve olumsuzlukların giderilmesinde, sağlık hizmetlerinde kalitenin geliştirilmesinde ve verimliliğin arttırılmasında yapay zekâ uygulamalarının kullanılmasının gerekliliği ortaya çıkmıştır. Bu gereklilikler aşağıdaki başlıklarda verilmiştir ${ }^{6}$

\subsection{Dünyada 65 Yaş ve Üstü Nüfustaki Artış}

Dünyada yaşlanan insan sayısının giderek artışı, artan yaşlı nüfusa yönelik uzun süreli tedavi ve bakım gerektiren sağlık hizmeti süreçlerinin de yönetimini gerektirmektedir. OECD verilerine göre 2017 y1lında Finlandiya'da 65 yaş ve üstü nüfusun toplam nüfusa oranı 2000 yılına göre \%6,1 artmıştır. 2017 yılında Türkiye'de 65 yaş ve üstü nüfusun toplam nüfusa oranı 2000 yılına göre \%2,9 artmışıır? OECD verilerine göre hem ülkemizde hem de dünyada nüfusun yaşlandığı anlaşılmaktadır. Türkiye'de TUIKK 2013-2015 yılları arası Hayat Tabloları istatistiğine göre doğuşta beklenen yaşam süresi 78 yıl iken, TUiK 2017-2019 yılları arası Hayat Tabloları istatistiğine göre doğuşta beklenen yaşam süresi 78,6 yıla yükseldiği belirtilmektedir. ${ }^{8}$ Önümüzdeki 30 yıl içerisinde dünyada 65 yaş üstü nüfusun 1.6 milyar olacağı tahmin edilmektedir.9 
2017 OECD verilerine göre Türkiye'de 100 bin kişiye 187 doktor düşmektedir. ${ }^{10} 2017$ OECD verilerine göre 1,4 milyarlık nüfusa sahip olan Hindistan'da 100 bin kişiye 78 doktor düşmektedir. Artan yaşlı nüfusa karşılık sağlı personeli istihdamı oldukça zordur. Bir doktorun ya da sağlı profesyonelinin istihdam edilebilmesi için hem insan kaynağı, eğitim için zaman ve gerekli çalışma ortamının oluşturulması gerekmektedir. Sınırlı kaynaklarla sağlık hizmeti talebinin karşılanabilmesi için akılcı teknolojiler kullanılması artık bir gerekliliktir. ${ }^{11}$

\subsection{Sağlığı Tehdit Eden Hastalıklar}

DSÖ'nün 2019 yılında açıkladığı raporda küresel anlamda insan sağlığını tehdit eden 10 büyük tehlikeye dikkat çekilmiştir. ${ }^{12}$ $\mathrm{Bu}$ raporda sanayinin ve teknolojinin gelişmesiyle artan hava kirliliği ve salgın hastalıklara neden olan virüsler, yetersiz sağlık hizmeti sebebiyle hastalık yaparak topluma yayılmasına neden olmaktadır. Bunun yanında sosyal, ekonomik ve kültürel nedenlerden dolayı temiz içme suyuna, besine ve sağlıklı yaşam ortamlarına sahip olunmamasından kaynaklı sağlık sorunları artmaktadır. Günümüzde yaşanan Covid-19 pandemisi de bugün tüm dünyada mücadele edilen önemli bir halk sağlığı sorunudur. Aynı raporda kalp hastalıkları, kanser, diyabet gibi bulaşıcı olmayan kronik hastalıkların dünyadaki ölümlerin \%70'inden fazlasına sebep olduğu belirtilmektedir. ${ }^{12}$ Kronik hastalıkların uzun süreli tedavi süreçlerini gerektirmesi sebebi ile hem maddi kaynaklar daha fazla harcanmakta hem de daha fazla sayıda iş gücü kaynağına ihtiyaç duyulmaktadır.

\subsection{Düşük Kalite Yaşam Standarttı}

Sağlığı tehdit eden bulaşıcı olan ya da olmayan hastalıklara insanların maruz kalmasının en önemli sebeplerinden biri de düşük kalite yaşam standarttıdır. Özellikle, tüm dünyada 30-69 yaş arası ölümlerin nedeni tütün ve alkol ürünlerinin tüketiminin artışıdır. Ayrıca, sağlıksız beslenme, fiziksel hareketsizlik, hava kirliliği de erken ölümlere neden olabilmektedir. ${ }^{12}$ Sosyo-ekonomik yönden yetersiz olan ülkelerde alım gücü düşük olduğundan ya da savaşlar, çatışmalar sebebi ile besin maddelerine, içme suyuna ve hijyen ürünlerine ulaşım oldukça sınırlıdır. Sonuç olarak, artan sağlık hizmeti talebine karşılık verilmesi ülkelerin sağlık sistemlerini zorlamaktadır.

\subsection{Maliyetlerin Artmast ve Rekabet}

Dünya genelinde 65 yaş üstü bireylerin yaşam sürelerinin artması beraberinde uzun süreli tedavi süreçleri ve yüksek maliyete neden olmaktadır. Her ülkenin, mevcut sağlık politikalarının uygulanması küresel dünyada oldukça güç hale gelmiştir. Bunun başlıca sebeplerinden biri aniden çıkan salgın hastalıklar çok sayıda bireyin hastalanmasına ve sağlık hizmeti talebi yaratmasına neden olmasıdır. Sınırlı sayıda istihdam ve kabiliyeti olan sağlık kurumları talebi karşılamakta yetersiz kalabilmektedir. Özellikle aşı, ilaç gibi tedavi ve korumaya yönelik çalışmalar oldukça maliyetli ve uzun yıllar gerektirmektedir. ${ }^{13,14,15}$

Sağlık hizmeti sunun devlet kurumu ya da özel kurumlar belli bir hizmet kalitesinin üzerinde sağlık hizmeti sunmak zorundadır. Sağlık işletmesinin varlığını devam ettirebilmesi için pazardaki rakiplerinden farklılıkları, üstünlükleri olmalıdır. Sağlık kuruluşunun kapasitesi düşünüldüğünde insan üstü çalışmalar doktor ve sağllk profesyonellerinden beklenilmektedir. Böyle bir durumda artan hasta sayısına karşılık kısıtlı insan gücü yanında yapay zekâ teknolojilerinden yararlanılması kaçınılmazdır. ${ }^{1}$

\subsection{Bilişim Teknolojilerindeki Gelişmeler}

İnternetin gelişmesi ile birlikte pek çok sektörde olduğu gibi sağlık sektöründe de dijital bir dönüşüm gerçekleşmektedir. Bu süreçte yapay zekâ uygulamaları bir çok alanda olduğu gibi sağlık hizmetlerinde ve yönetiminde de meydana gelen problemlerin çözülmesinde, hastalıkların teşhis ve tedavisinde, hastalıkların tahmin edilmesi ve daha bir çok konuda kullanılmaya başlamıştır. Sağlıkta bilişim teknolojilerinin en önemli uygulama alanlarından biri de yapay zekâ uygulamalarıdır. ${ }^{4}$

\section{Sağlık Hizmetleri ve Yönetiminde Yapay Zekânın Uygulama Alanları}

\subsection{Yapay Zekânın Yönetim Amaçlı Uygulama Alanları}

Genel sağlık yönetimi: MHRS kullanım oranları, eNabız verileri vb. gibi veriler kullanılarak hastaneye başvurular tahmin edilebilir, acil servislerde bekleme süreleri azaltılabilir, ambulans ulaşım süreleri standardize edilebilir, bebek/çocukların aşılamaları takip edilebilir. 
Dokümantasyon yönetimi: Elektronik Sağlık Kayıt Sistemleri ile sağlık profesyonellerin bilgilerinin düzenlenmesi, saklanması ve yeniden kullanılması sağlanabilir. NLP (Doğal Dil İşleme) araçlarıyla doktor ve sağlık profesyonellerin sesli kayıtları ile raporlar yapay zekâ tabanlı uygulamalarla çok kısa süre yazdırılabilir.

Maliyet ve kalite yönetimi: Sağlık kuruluşları diğer işletmelerin aksine, sağlık hizmeti sunarken hastayı müşteri olarak görmemelidir. Sağlık kuruluşunun varlığını idame ettirebilmesi için katlanması gereken maliyeti azaltıp, sunduğu hizmetin kalitesini arttırması gerekmektedir. Centerstone Araştırma Enstitüsü yaptığı bir araştırmada yapay zekâ kullanarak tanı koymanın, geleneksel tanı koymaya göre daha az maliyetli olduğunu göstermiştir. Bu çalışmada, rastgele seçilmiş 500 hasta bireyin fiziksel performansları, hastalıkları ile ilgili sonuçları yapay zekânın algoritmasına göre karar verme modelleriyle kıyaslanmıştır. Sonuç olarak, birim başına maliyetler arasında anlamlı bir farklılık olduğu ortaya çıkmıştır. Yapay zekâ algoritmaları 189 dolar maliyet çıkarırken, geleneksel yöntemlerin maliyeti 497 doları bulduğu görülmüştür. ${ }^{16}$ Sağlık işletmesinin maruz kalabileceği risk ve maliyetleri önceden tespit edebilen yapay zekâ uygulamaları kullanılmaktadır.

Sağlık kurumlarının kapasitesinin akılcı kullanımı: Boş yatak kapasitesinin anlık olarak kontrol edilmesinde kullanılabildiği gibi taburcu edilen hastaların tekrar yatış yapma olasılı̆̆ı da hesaplanabilmektedir. Özellikle, son yıllarda acil servislerde hasta sayısı ve bu servislere talebin artması yoğunluğun önceden hesaplanabilmesi için bir gereksinim doğurmuştur. Yapılan bir çalışmada, Long Short-Term Memory (LSTM) derin öğrenme modeli kullanılarak zamana bağlı acil servis yoğunluğunu hesaplayan, ilerleyen gün ve aylar için günlük hasta sayılarını önceden hesaplayan bir uygulama yapılmıştır. ${ }^{17}$ Covid-19 gibi salgınlarda sınırlı sayıda yatağın efektif bir şekilde kullanılması açısından oldukça faydalı kullanım alanı olabilir.

Sağlık hizmeti ve yönetimindeki olumsuzlukların iyileştirilmesi: Hasta kayıtlarının arşivlenmesinde yaşanan sıkıntılar ve siber saldırılar gibi sebeplerden meydana gelen olumsuzlukların giderilmesinde kullanılabilir. Her geçen saniye dünyanın bir ucundan sağlık ile ilgili veriler insanların giydikleri cihazlar, kullandıkları uygulamalar, elektronik sağlık kayıtları olarak üretilmektedir. Sağlık verilerinin oluşturduğu büyük verileri analiz edebilmek, arşivlemek, gerektiğinde kullanabilmek maliyetli ve insan gücü gerektirmektedir. ABD’de bulunan Montefiore Health System, Intel ile işbirliği yaparak çeşitli hasta popülasyonuna daha etkili bir hizmet sunabilmek üzere çok büyük miktardaki hasta verilerindeki ortak modelleri görmek için yapay zekâ çözümlerini ve analizlerini devreye almıştır. ${ }^{18}$ Bu şekilde, insan kaynaklı hataların azaltılması, ilaç dozu hesaplamalarındaki yanlışlıklardan kaynaklanan ilaç israfı ve hastaya uygulanan yanlış tıbbı tedavi sonucu oluşan zararların engellenmesini mümkün olabilmektedir.

Uzaktan önleyici ve tamamlayıcı sağlık hizmeti sunumu: Sağlık hizmeti sunumu yanında bireyin sağlığını koruması, hastalanmasının önlenmesi oldukça önemlidir. Sağlı̆̆ın geliştirilmesinde ve takibinde hastaneye gitmeden uzaktan takip edebilen sistemler sayesinde sınırlı kaynaklarda \%60 oranında tasarruf sağlanabilir. Dijital sağlık ortamında karar destek sistemleri ve makine öğrenmesi önemli rol oynamaktadır. Yapılan bir çalışmada, çocuklarda obezitenin engellenmesi için makine öğrenmesi tabanlı bir karar destek sistemi önerilmiştir. Yapılan incelemede makine öğrenmesi tabanlı karar destek sisteminin yapay sinir ağları ile kullanılması durumunda obezite riski olan çocukları öngörebildiği tespit edilmiştir. ${ }^{1}$

\subsection{Yapay Zekânın Klinik Amaçlı Uygulama Alanları}

Yapay zekânın klinik amaçlı kullanılması ile ilgili dünya genelinde pek çok çalışma mevcuttur. Çok geniş kapsamlı olmasına rağmen aşağıdaki başlıklar ile kategorize edebiliriz. ${ }^{4}$

Halk sağlığı yönetimi: yapay zekâ uygulamaları, bireylerin, hastalıklar hakkında bilinçlendirilmeleri, çok sayıda hedef kitleye ulaşarak tarama testleri yapılması ve değerlendirilmesi gibi konularda kullanılabilmektedir. Covid-19 pandemisi nedeni ile kişilerin kendilerini riskli görülen bölgelerden koruması, hastaneye gitmeden mevcut sağl1k durumunun değerlendirilmesi ile günümüzde yapay zekâ uygulamaları kullanılmaktadır.

Covid-19 pandemisi sürecinde FITAS (Filyasyon ve izolasyon takip sistemi) ile filyasyon yapılan alanda veriler anlık olarak sisteme kaydedilerek, hızlıca analiz edilmesinde kullanılmaktadır. Ülkemizde ilk Covid-19 vakasından sonra tespit edilen vakalar için filyasyon çalışmaları yapılarak, Covid-19 pandemisi yayılım haritası çıkarılmaktadır. FITAS ile elde edilen veriler doğrultusunda alınan tedbirle birlikte vaka artış hızının düşürülmesi amaçlanmaktadır. ${ }^{20}$ 
Erken tanı ve acil müdahale: Özellikle kanser hastalıklarının erken teşhisi ve tedavisi son derece önemlidir. Hastalık gözle görülür belirtiler vermesini beklemeden hastalığın başlangıç evresinde teşhis edilmesi hayat kurtarıcıdır. Çeşitli makine öğrenmesi algoritmaları hastalıkların önceden tahmin edilmesinde kullanılmaktadır. Parkinson, erken tanının çok önemli olduğu bir hastalıktır. Yapılan bir çalışmada EEG (elektroansefalogram) sinyalleri, fotoğraf simülasyonları, PDC (partial directed coherence) verilerini makine öğrenmesi teknikleri kullanılarak hasta kişiler, ilaç kullanması gerekenler ve sağl1klı bireyler olarak sınıflandırılmıştır. Çalışmada testlerde \%99 oranında doğruluk gözlemlenmiştir. ${ }^{21}$

Dünyada yaygın olarak bilinen yapay zekâ sağlı hizmetleri destek sistemlerinden biri de IBM Watson'dur. Makine öğrenimi ve doğal dil işleme yetenekleri ile bu sistem, doktorların hastaların elektronik sağlık kayıtlarının incelemelerine ve aramayla ilgili tıbbi araştırma yayınlarını ve kılavuzlarını incelemelerine yardımcı olmak için tasarlanmıştır. Çift kör bir çalışmada, bir tümör kurulu tarafından alınan kararlarla Watson Onkoloji Sistemi (Watson for Oncology) tarafindan alınan kararları karşılaştırmıştır. Sonuçlar, sistem tarafından yapılan önerilerin \%90'ının tümör kurulu tarafından yapılan önerilere uygun olduğunu göstermiştir. ${ }^{22}$

Radyoloji görüntülerinin değerlendirilmesi: Radyoloji görüntülerinin incelenmesi, raporlanması, raporların hastanın doktoru tarafından değerlendirilmesi, uzun bir süreçtir. Yapay zekâ uygulamaları kullanılarak, radyoloji görüntülerinde çeşitli nodüllere/lezyonlara rastlananılar hastaların doktorlarına görüntülerin gönderilmesi hem zamandan hem de iş yükünden tasarruf sağlayabilmektedir. Zamanında teşhis konulması için hastaya kaliteli bir sağlık hizmeti de böylece sunulabilmektedir. Yapay zekânın radyoloji alanında kullanımı ile ilgili yapılan bir çalışmada kemik yaşını değerlendirmek için Evrişimsel Sinir Ağları (CNN) kullanılmıştır. Çalışma sonucunda CNN ile pediatrik el radyografilerin yaş değerlendirmeleri, radyologların değerlendirmelerine benzer doğrulukta çıkmıştır. ${ }^{23}$

Test sonuçlarının takibi: Bir çok hastalığın tekrardan ortaya çıkması ya da başka bir hastalığa sebep olması gibi nedenlerden ötürü hastalığın takibi son derece önemlidir. Hastaya yapay zekâ tabanlı mobil cihazlar giydirilerek, dünyanın neresinde olursa olsun hasta, doktoru tarafından takip edilebilmektedir. Hastanın yaptırdığı test sonuçları hastanın izni ile sisteme kayıt edildiği için doktor yer/zaman fark etmeksizin hastasının verilerine ulaşabilmektedir.

Tedavi: Olası tedavi protokollerinin oluşturulmasında ve hangisi kullanıldığında hastaya ne gibi yarar/zarar sağlayabileceğini yapay zekâ tabanlı sistemlerle tahmin etme yaparak doktora destek olunmaktadır. Hindistan'da bir Kanser Merkezi'nde onkologlar tarafından meme kanseri hastaları için uygulanan tedaviler; geriye dönük gözlemsel bir çalışmada "Watson for Oncology" adındaki yapay zekâ sistemi kullanılarak karşılaştırılmıştır. Sistem, genel olarak kanser evresi ve yaşına göre \%93’lük (\%80-\%97) uyum göstermiş̧tir. ${ }^{24}$ Yapılan başka bir çalışmada; birden fazla hastaneden doğumsal kataraktlarla ilgili veriler elde edilmiştir. Yapay zekâ tabanlı kullanılan sistem ile çerçevenin tanımlama ağlarında \% 98,25 doğruluk ve tedavi önerileri için \% 92,86 doğruluk gösterdiği belirlenmiştir. ${ }^{25}$ Yapay zekâ, oftalmolojide mükemmel bakım sağlama amacına hizmet edebilecek çeşitli kullanımlar göstermiştir. ${ }^{26}$

Yapay zekâ destekli robotik ameliyat: Günümüzde bazı hastanelerde kullanılmaya başlamıştır. Yer/zaman farkı olmaksızın anlık dünyanın herhangi bir ucundan doktor destekli yapay zekâ destekli ameliyatlar yapılmaktadır. Robotlar yardımcı cerrah olarak ameliyatta da kullanılmaktadırlar. Da Vinci Cerrahi Sistemi (The da Vinci Surgical System), en çok tercih edilen robotik cerrahi sistemlerden biridir. ${ }^{27}$ Bunun yanında otonom ameliyat yapabilen yapay zekâ destekli robotlar için çalışmalar devam etmektedir.

Patoloji sonuçlarının değerlendirilmesi: Çok nadir görülen hücre görüntülerinin varlı̆̆ı, boyamadan kaynaklı hatalar, patoloğun yorgun olmasından kaynaklı hataların azaltılması amacıyla kullanılmaktadır. Sepsis, ölüm oranı yüksek bir hastalık olup hastalarda ilgili patojenin tespiti zor bir süreçtir. Yapılan bir çalışmada klinik-metabolik sepsis vakalarını içeren bir veri tabanı kullanılarak farklı makine öğrenmesi teknikleri ile bir sınıflandırıcı model oluşturulmuştur. Veri tabanında 100 hastaya ait veri kullanılarak 29 klinik ve metabolik özellikler paneline bakılmıştır. Elde edilen en iyi AUC değeri (area under cure) $0,94^{\prime}$ tür. Çalışama sonucuna göre seçilmiş panel ile, sepsisli hastaları ayırt etmek için güçlü biyobelirteçler olabileceği ortaya konulmuştur. ${ }^{28}$ 
İlaç tedavisi takibi: Hasta bireylerin ilaçlarını doğru dozda, doğru zamanda, doğru yöntemle alması önemlidir. Yapay zekâ uygulamaları, Alzheimer gibi kronik hastalıklarda ilaçların takip edilmesi için kullanılmaktadır. Yüz tanıma teknolojisi ile yapay zekâ tabanlı sistemler kullanılarak, hastanın yüzü tanınmakta, hastanın almak istediği ilacın doğru olup olmadığı tespit edilebilmektedir.

Gelişen teknoloji Parkinson hastalığının tedavisinin uzaktan takibi için yeni yöntemler sunmaktadır. Yapılan bir çalı̧mada hastaların motor sinir davranışları geliştirilen bir cihazda tuşlara basışş şekil ve sürelerine bakılarak 6 ay süre ile gözlemlenmiştir. Elde edilen veriler üzerinde geliştirilen yeni bir derin öğrenme algoritması ile hasta durumları sınıflandırılmıştır. Bu çalışma kullanılan gözetimsiz motor sinir verilerinin, ilaçlara verilen tepkinin takibi ve gözetiminde kullanılmasına bir örnektir. ${ }^{29}$

İlaç geliştirme: İlaç geliştirme pahalı, zaman alan ve yoğun emek isteyen süreçleri kapsamaktadır. Yapay zekâ teknolojileri kullanılarak moleküler düzeyde ilaç geliştirme çalışmalarına katkı sağlanmaktadır. Örneğin, pek çok ilaç veya besin takviyesi gibi maddeler insan vücudunda hücre bileşenlerine oksidatif zararlar verebilmektedir. Bu tip maddelerin verebileceği zararların ön görülmesinde hidrojen atom transferi kullanılmakta ve sonuçların değerlendirilmesi için kuantum bilgisayarlar gerekmektedir. Bu etkinin simüle edilip, tahmin etmesi için makine öğrenmesi kullanılarak bir model önerilmiştir. Böylece, bu hesaplamanın yapılabilmesi için donanım ve zaman maliyeti ciddi ölçüde optimize edilmiştir. ${ }^{30}$

Kişiye özel tedavi: Günümüzde bazı hastalıkları tedavi etmede geleneksel tedavi yöntemleri yetersiz kalmaktadır. Genetik yapı, bağışıklık sistemi, yaşam tarzı gibi farklılıklar sebebiyle kişiye özel tedavi yöntemleri geliştirilmesi gerekmektedir. Kişiye özgü tedavi yöntemleri geliştirilmesinde, yapay zekâ uygulamalarından yararlanılmaktadır. Kore'de yapılan bir çalışmada Technology Acceptance Model (TAM) kullanılarak hastaların davranışları nelerden zevk aldıkları, birlikte yaşadığı kişi sayısı ve karakterleri gibi parametreleri göz önünde bulundurarak kişiye özel evde bakım hizmeti sağlayan bir robot önerilmektedir. Bu çalışmada 403 hasta ve hastanın ailesine ait bilgiler gözlemlenmiştir. Robotlar ile birlikte geçirdikleri süre değerlendirilip, sağlıklı yaşam konusundaki katma değeri incelenmiştir. Özellikle robotun kişiye özel davranması ve kullanım kolaylığı kullanıcıların en beğendiği faktörler olmuştur. ${ }^{31}$

Tedavi sonrası klinik karar destek: Klinik karar destek sistemleri doktorlara tedavi sonrası komplikasyonlar ile uygulanan tedavinin devam ettirilip/ettirilemeyeceği konusunda destek olmaktadır.

Hastaya evde bakım: Bilindiği üzere ortalama yaşamdan beklenen yaşam süresi artmıştır. Buna bağlı kronik hastalıkları, Alzheimer ve bunama gibi rahatsızlı̆ıı olan birey sayısı gün geçtikçe artmaktadır. Bunun yanında evde yalnız başına yaşayan yaşlı birey sayısı azımsanmayacak sayıdadır. Örneğin evde bakım hizmetleri ile ilgili Finlandiya'da 2018 yılında 68,400 hasta için sağl1k kontrolleri evden sanal olarak gerçekleştirilmiştir. 250 hasta için belirli testler 60 adet medikal robot kullanılarak yapılmıştır. ${ }^{32}$ Yapay zekâ tabanlı robotlar ile hastaların evlerinde temel sağlık verilerinin, ilaçlarının takibi, gerekli durumlarda acil sağlık ekiplerinin gelmesini sağlamaktadır.

\section{Sağlık Hizmetleri Ve Yönetiminde Yapay Zekâ Uygulamalarının Avantajları/Dezavantajları}

\subsection{Sağlık Hizmetleri ve Yönetiminde Yapay Zekâ Uygulamalarının Avantajları}

Sağlık hizmetleri ve yönetiminde yapay zekâ uygulamaları ile ilgili çalışmalarda, yapılan işlerin yeniden tanımlandığı, kalite ve verimliliğin arttığı, maliyetlerin azaldığı, insan/sistem kaynaklı hataların azaltıllığı belirtilmiştir. Yapay zekâ uygulamalarının sağladığı bazı avantajlar aşağıdaki gibi sıralanabilir: 33,34

- Doktorlardan gelen girdiler koordineli olarak geliştirilirse, girdiler ve çıktılar uygun şekilde tanımlanabilirse, yapay zekâ sayesinde hastalık karakterizasyonu, hastalık tespiti ile raporlamada bir standardizasyon sağlanabilir.

- Sürekli çalışmalar yapıldığı için problemlerin çözüm önerileri geliştirilmeye çalışılmaktadır. Birden fazla algoritma birleştirilerek ortaya daha iyi bir algoritma çıkarılarak (tümleştirme yöntemi) yeni çözüm önerileri sunulabilmektedir.

- Nitel ve nicel veri gruplarında başarı sağlar. Örneğin, tahlil sonuçlarının değerlendirilmesi, kanser tanısının konmasının tahmin edilmesinde kullanılabilir. 
- Farklı klinik alanlardan (radyoloji, biyokimya, mikrobiyoloji, patoloji vb. gibi) veriler kullanılarak çeşitli bilgiler elde edilebilir. Bu elde edilen bilgilerin yapay zekâ teknolojileri kullanılarak anlamlı bilgilere dönüştürülerek çeşitli hastalıkların teşhisinde kullanılabilir.

- Zaman tasarrufu sağlar.

- Emek isteyen, maliyetli ve zaman alan işleri otomatikleştirerek işleri daha yapılabilir hale getirir.

- Verimliliği artırarak, görüntülerin daha hızlı ve güvenilir raporlanmasını sağlar.

- Arşivlemede fiziksel alan sıkıntısı yaratmadan depolamayı sağlar.

- Manuel ve beceri isteyen birçok işi otomatize ederek standardize edilmesini sağlar.

- İş̧ yükünü azaltır.

- Göz taraması yapay zekâ teknolojileri kullanılarak yapıldığında, doktora başvuru yapacak hastalar önceden filtrelenir. Bu şekilde, hasta olmayanların sağlık kuruluşlarına başvurmaları önlenirken, hastalık tespit edilen kişilerin daha hızlı doktora yönlendirilmesine yardımcı olur. Dolaylı olarak, sağlık maliyetlerinin hem hesaplanmasında hem de maliyetlerin azaltılmasında önemli rol oynar.

\subsection{Sağllk Hizmetleri ve Yönetiminde Yapay Zekâ Uygulamalarının Dezavantajları}

Yapay zekâ uygulamalarının dezavantajlarından bazıları aşağıdaki gibidir: ${ }^{33,34}$

- Algoritmayı geliştiren mühendislerin yeterli tıbbi bilgiye sahip olmaması, radyoloğun iş akışının anlaşılmamasına bağlı oluşabilecek hatalar. Bununla birlikte, algoritmayı kullanacak radyoloğun konuya hâkim olmaması yanlış kullanım ve yorumlamaya bağlı hatalara sebep olabilir. Bu yüzden multidisipliner bir ekip çalışması gereklidir. Radyolog ve algoritmayı geliştiren mühendis iş birliği içinde olmalıdır. Görüntülerin eğitimi sırasında mutlaka radyolog görüntüleri incelemelidir.

- Görüntü analizi için doğru ve yeterli sayıda veri seti gereklidir. Veri setlerinin oluşması için belli bir zaman gerekmektedir ayrıca, veri setlerinin doğruluklarının kontrol edilmesi süreçleri de oldukça zahmetlidir.

- Kullanılan veri seti çok önemlidir. İyi eğitim gerçekleşmezse güvenilir olmayan sonuçlar verebilir.

- Veri seti yeterli sayıda örnek içermiyorsa yanıltıcı sonuçlar verebilir.

- Sadece görüntülerin kullanılması yeterli sonuç vermeyebilir. Tanı için doğru özellikler hekim ile birlikte karar verilmesi gerekir.

- Klinik ilaç tedavisi uygulamalarında henüz çok somut örnekleri yoktur.

- Sorumluluk ve etik açısından risk teşkil etmektedir.

- Çok sayıda görüntünün arşivlenebilmesi için dijital görüntü haline getirilmesi gerektiğinden, büyük bir iş yüküne de sebep olmaktadır.

- Teknolojinin ilerlemesiyle birlikte yapay zekâ tabanlı daha güçlü modeller geliştirilmelidir.

- Sistemin kurulumu için gerekli cihazların ve malzemelerin yetersizliği ve mali yetersizlikler için gerekli önlemler alınmalıdır.

- Ahlaki ve etik boyutu ile ilgili birçok soru cevapsız kaldığı için belirsizlik mevcuttur. 


\section{Tartışma}

Yapay zekâ uygulamaları uzay, askeri, pazarlama, turizm vb. gibi pek çok sektörde kullanım alanı bulmaktadır. Günümüzde sağlık hizmetleri ve yönetiminde de yapay zekâ uygulamaları kullanılarak erken tanı, tedavi, rehabilitasyon, sağlığın geliştirilmesi vb. gibi süreçlerde uygulama alanları mevcuttur. Sınırlı kaynaklarla, geniş bir kitleye kaliteli ve düşük maliyetli, etkili, zamanında ve coğrafi bölge ayrımı yapmaksızın sağlık hizmeti sunmak oldukça zordur. Artan sağlık hizmeti ihtiyacı karşısında sınırlı sağlık insan gücü nedeniyle yapay zekâ uygulamalarının kullanılması kaçınılmazdır. Bu doğrultuda bireylerin yaşam kalitelerinin arttırılması, sağlık maliyetlerinin azaltılması, yerinde ve zamanında ve yeterli sağlık hizmeti sunumu açısından süreçlerin optimize edilmesi ve süreçlere yapay zekâ teknolojilerinin entegre edilmesi artık bir gerekliliktir.

Küresel boyutta sağlık sektörü diğer sektörlerde olduğu gibi dünyadaki teknolojik gelişmeleri takip etmektedir. Bu sektörün paydaşları olan sigorta şirketleri, ilaç ve medikal cihaz üreten firmalar, hizmet sunumunda yer alan kurum/ kuruluşlar sağlık sektörünün büyümesi ve geliştirilmesi için büyük önem arz etmektedir. ${ }^{35}$ Ülkelerin uyguladığı sağlık politikalarının temelini maliyeti düşük, kaliteli ve erişilebilir sağlık hizmeti başlıkları oluşturmaktadır. Sağlık sektöründe pazardan pay almak ve sektördeki varlığının devam ettirmek isteyen paydaşlar artan nüfus, kronik hastalık ve salgınlar, yaşam standartlarındaki değişmeler, sağlık okuryazarlığının artışı ve kriz ortamlarında sürdürülebilir sağlık hizmeti için yeni yollar aramaktadırlar. Geleneksel yöntemlerin sebep olduğu dezavantajları avantaja çevirecek çözüm önerilerinin başında yapay zekâ uygulamaları gelmektedir.

Günümüzde sağlık alanında ve teknolojide meydana gelen gelişmeler doğrultusunda hasta odaklı dijital bir sağlık ekosistemi yaratılmaya başlanmıştır. Umut vaat eden çözümleriyle yapay zekâ uygulamalarının kullanımında gerekli yasal düzenlemelerin yapılması önerilmektedir.

Hakem Değerlendirmesi: Dış bağımsız.

Çıkar Çatışması: Yazarlar çıkar çatışması bildirmemiştir.

Finansal Destek: Yazarlar bu çalışma için finansal destek almadığını beyan etmiştir.

Yazar Katkıları: Çalışma Konsepti/Tasarım- B.A., Ü.V.; Veri Toplama- B.A., Ü.V.; Veri Analizi/Yorumlama- B.A., Ü.V.; Yazı Taslağı- B.A., Ü.V.; İçeriğin Eleştirel İncelemesiB.A., Ü.V.; Son Onay ve Sorumluluk- B.A., Ü.V.

Peer-review: Externally peer-reviewed.

Conflict of Interest: The authors have no conflict of interest to declare.

Grant Support: The authors declared that this study has received no financial support.

Author Contributions: Conception/Design of Study- B.A., Ü.V.; Data Acquisition- B.A., Ü.V.; Data Analysis/Interpretation- B.A., Ü.V.; Drafting Manuscript- B.A., Ü.V.; Critical Revision of Manuscript- B.A., Ü.V.;Final Approval and Accountability- B.A., Ü.V

\section{Kaynaklar/References}

Veranyurt U, Deveci AF, Esen MF, Veranyurt O. (2020). Disease Classification By Machine Learning Techniques: Random Forest, K-Nearest Neighbor and Adaboost Algorithms Applications. Usaysad Derg. 2020; 6(2):275-286.

Hayran O. (2012). Sağlık Yönetimi Yazıları. Ankara: Sage Yayıncılık.

Elmas Ç. 2018. Yapay Zekâ Uygulamaları. 4. Bask1. Ankara: Seçkin Yayıncılık, 25-45.

Akalın B. 2020. Sağlık Hizmetleri ve Yönetiminde Yapay Zekâ. İstanbul: Hiper Yayıncılık, 125-132.

Qian, Z., Alaa, A. M., \& van der Schaar, M. (2020). CPAS: the UK's National Machine Learning-based Hospital Capacity Planning System for COVID-19.

Jiang F, Jiang Y, Zhi H, et al. (2017). Artificial intelligence in healthcare: past, present and future. Stroke and Vascular Neurology;2: e000101. doi:10.1136/ svn-2017-000101.

OECD. Organisation for Economic Co-operation and Development. (2019). Health at a Glance 2019: OECD Indicators. Paris: OECD Publishing; 2019. doi:10.1787/4dd50c09-en.

TUİK. Türkiye İstatistik Kurumu. https://www.tuik.gov.tr/ (Erişim Tarihi: 01.11.2020).

Öcal H., Doğru İ. A. ve Barışçı N. (2019). Akıllı ve geleneksel giyilebilir sağlık cihazlarında nesnelerin interneti. Politeknik Dergisi, $22(3)$ : 695-714.

T.C. Sağlık Bakanlığı Sağlık İstatistikleri Yıllığı 2018. https://dosyasb.saglik.gov.tr/Eklenti/36134,siy2018trpdf.pdf?0 (Erişim Tarihi: 01.11.2020).

Çoban, H. (2009). Sağlık Ekonomisi ve Türkiye'de Sağlık Hizmetlerinin Yeniden Yapılandırılması. Dokuz Eylül Üniversitesi, Doktora Tezi, İzmir.

World Health Organization (WHO). "Ten threats to global health in 2019”, https://www.who.int/emergencies/ten-threats-to-global- health-in-2019 (Erişim Tarihi: 01.11.2020). 
Fleming, N. (2018). How Artificial intelligence is changing drug discovery. Naature, 557(7707), ss 55-57. Doi: 10.1038/d41586-018-05267-x.

Hecht, D. (2011). Applications of Machine Learning and Computational Intelligence to Drug Discovery and Development. Drug Development Research, 72: $53-65$.

Gavin, B., Hayden, J., Adamis, D., \& McNicholas, F. (2020). Caring for the psychological well-being of healthcare professionals in the Covid-19 pandemic crisis. Ir Med J, 113(4), 51.

Mesko, B. (2017). Yapay Zekâyla Tıbbi Karar Almak. B. Mesko içinde, Tibbın Geleceğine Yolculuk (s. 174-183). İstanbul: Optimist Yayın Grubu.

Kadri, F., Baraoui, M., \& Nouaouri, I. (2019, September). An LSTM-based Deep Learning Approach with Application to Predicting Hospital Emergency Department Admissions. In 2019 International Conference on Industrial Engineering and Systems Management (IESM) IEEE. (1-6).

İntel. (2018). Sağlık Dönüşümü. https://www.intel.com.tr/content/www/tr/tr/healthcare-it/healthcare-overview.html (Erişim Tarihi: 01.11.2020).

Triantafyllidis, A., Polychronidou, E., Alexiadis, A., Rocha, C. L., Oliveira, D. N., da Silva, A. S., Freire, A. L., Macedo, C., Sousa, I. F., Werbet, E., Lillo, E. A., Luengo, H. G., Ellacuría, M. T., Votis, K., \& Tzovaras, D. (2020). Computerized decision support and machine learning applications for the prevention and treatment of childhood obesity: A systematic review of the literature. Artificial Intelligence In Medicine, 104.

T.C. Sağlık Bakanlığı Sağlık Bilgi Sistemleri Genel Müdürlüğü, FİTAS (Filyasyon ve İzolasyon Takip Sistemi). https://sbsgm.saglik.gov.tr/TR,73584/ fitas.html (Erişim Tarihi: 01.11.2020).

Yan, Y. (2020). MCI progression classification for early diagnosis of Alzheimer's disease using machine learning and deep learning methods. Res. Biomed. $36: 311-331$.

Curioni-Fontecedro, A. (2017). A new era of oncology through artificial intelligence. ESMO Open; 2(2): e000198.

Larson, D.B., Chen, M.C., Lungren, M.P., Halabi, S.S., Stence, N.V., Langlotz, C.P. 2018. Performance of a deep-learning neural network model in assessing skeletal maturity on pediatric hand radiographs. Radiology 287, 313-322.

Somashekhar, S.P., Sepulveda, M.J., Puglielli, S., Norden, A.D., Shortliffe, E.H., Rohit Kumar, C., Rauthan, A., Arun Kumar, N., Patil, P., Rhee, K., Ramya, Y. 2018. Watson for Oncology and breast cancer treatment recommendations: agreement with an expert multidisciplinary tumor board. Ann. Oncol. 29, 418-423.

Long E, Lin H, Liu Z, et al. 2017. An artificial intelligence platform for the multihospital collaborative management of congenital cataracts. Nat Biomed Eng;1. Article number 24.

Ting, D. S. W., Pasquale, L. R., Peng, L., Campbell, J. P., Lee, A. Y., Raman, R., ... \& Wong, T. Y. (2019). Artificial intelligence and deep learning in ophthalmology. British Journal of Ophthalmology, 103(2), 167-175.

Guo J, Li B (2018) The application of medical artificial intelligence technology in rural areas of developing countries, Health Equity 2:1, 174-181.

Zheng, L., Lin, F., Zhu, C., Liu, G., Wu, X., Wu, Z., Zheng, J., Xia, H., Cai, Y., \& Liang, H. (2020). Machine Learning Algorithms Identify Pathogen-Specific Biomarkers of Clinical and Metabolomic Characteristics in Septic Patients with Bacterial Infections. BioMed Research International, 1-11.

Pedrosa, T. Í., Vasconcelos, F. F., Medeiros, L., \& Silva, L. D. (2018). Machine Learning Application to Quantify the Tremor Level for Parkinson's Disease Patients. Procedia Computer Science, 138, 215-220.

Muraro, C., Polato, M., Bortoli, M., Aiolli, F., \& Orian, L. (2020). Radical scavenging activity of natural antioxidants and drugs: Development of a combined machine learning and quantum chemistry protocol. Journal of Chemical Physics, 153(11), 1.

Thadatritharntip, W., \& Vongurai, R. (2020). Artificial Intelligence Healthcare: An Empirical Study on Users' Attitude and Intention to Use toward a Personal Home Healthcare Robot to Improve Health and Wellness Conditions in Bangkok, Thailand. UTCC International Journal of Business \& Economics, 12(1), 3-25.

Itkonen, P. (2019). Artificial intelligence in Home Care Settings in South Karelia Social and Healthcare District in Finland. 2019 IEEE World Congress on Services (SERVICES), 2642-939X, 238-239.

Şensu S, Erdoğan N, Gürbüz, YS. 2020. Patolojide Dijital Çağ ve Yapay Zekâ: Temel Bilgiler. Türkiye Klinikleri J Med Sci; 40(1):104-12.

Oral, C. 2011. Sayısal Mamografi Görüntülerine Yapay Zekâ Yöntemlerinin Uygulanması. Doktora Tezi, Ondokuz Mayıs Üniversitesi, Samsun, 35-56.

Thinktech STM. İleri Sağlık Teknolojileri I - Akıllı Sağlık Uygulamaları Ve Veri Analizi İle Sağlık Sorunlarını Tanımlamak (Araştırma Raporu 2019). http://thinktech.stm.com.tr (Erişim Tarihi: 01.11.2020). 
